\title{
PENGARUH GENETIC PERSONALITY DAN AUTHORITATIVE PARENTING STYLE TERHADAP PENDIDIKAN KARAKTER DI AYA SOPHIA ISLAMIC SCHOOL
}

\author{
Masduki Asbari ${ }^{1}$, Wakhida Nurhayati ${ }^{2}$, Agus Purwanto ${ }^{3}$ Firdaus Putra ${ }^{4}$ \\ ${ }^{1}$ STIE Insan Pembangunan, masduki@ipem.ac.id \\ ${ }^{2}$ Aya Sophia Islamic School, wakhida.nurhayati@yahoo.com \\ 3Universitas Pelita Harapan, agozpor@gmail.com \\ ${ }^{4}$ STIE Insan Pembangunan, firdausputraa@gmail.com
}

*Corresponding Author. Email: ${ }^{1}$ masduki@ipem.ac.id

\begin{abstract}
Abstrak
Pendidikan karakter penting untuk menjadi mainstream pokok pendidikan di Indonesia baik di ranah formal, nonformal maupun informal. Terdapat beberapa faktor yang mempengaruhi pengembangan karakter anak, di antaranya adalah genetic personality dan pola asuh di keluarga (parenting style). Penelitian ini bertujuan untuk mengetahui pengaruh genetic personality, khususnya berbasis konsep STIFIn dan pengaruh parenting style, khususnya tipe pengasuhan authoritative parenting style terhadap pengembangan karakter anak. Jenis penelitian adalah korelasional menggunakan metode survei dengan pendekatan penelitian kuantitatif. Teknik pengumpulan data adalah dengan menyebarkan angket kepada populasi melalui online dengan teknik simple random sampling. Populasi penelitian ini adalah orang tua siswa Aya Sophia Islamic School sebanyak 184 orang. Kuesioner yang kembali dan valid sebanyak 144 sampel. Kuesioner (angket) yang disusun berdasarkan skala Likert. Instrumen yang digunakan untuk mengukur pola asuh parenting style merupakan hasil modifikasi dari Parenting Style Questionnaire (PSQ) Robinson et al. (1995) dan Roman et al. (2015). Instrumen untuk mengukur genetic personality diadaptasi dari Poniman dan Mangussara (2013), sedangkan untuk mengukur pengembangan karakter anak menggunakan adaptasi dari Poniman dkk. (2014). Analisis pada penelitian ini menggunakan SEM (Structural Equation Model) dengan software SmartPLS versi 3.0. Hasil penelitian menunjukkan bahwa genetic personality dan authoritative parenting style berpengaruh positif dan signifikan terhadap pengembangan karakter anak.
\end{abstract}

Keywords: parenting style, pengembangan karakter anak, genetic personality, pola asuh, STIFIn Personality

\section{PENDAHULUAN}

Indonesia saat ini menghadapi tantangan besar, yaitu desentralisasi dan era globalisasi total. Kunci sukses dalam menghadapi tantangan tersebut adalah dengan mempersiapkan kualitas sumber daya manusia yang paripurna, handal dan berbudaya (Puspitawati, 2012). Maknanya, bahwa yang mampu menyelamatkan kondisi bangsa adalah sumber daya manusia yang berkarakter. Bung Karno sebagai salah satu bapak pendiri bangsa menegaskan: "Bangsa ini harus dibangun dengan mendahulukan pembangunan karakter (character building) karena karakter inilah yang akan membuat Indonesia menjadi bangsa yang besar, maju dan jaya, serta bermartabat (Samani, 2011).

Pendidikan karakter telah mewarnai kurikulum di Indonesia sejak orde lama, memakai istilah pendidikan budi pekerti dengan penekanan pada hubungan antar manusia, antara siswa dan guru, antara siswa dan orangtua, dan antar siswa. Hingga saat ini, implementasi pendidikan karakter masih menjadi mainstream pokok. Pada puncak peringatan Hari Pendidikan Nasional 2 Mei 2010, Bapak Susilo Bambang Yudhoyono selaku Presiden Republik Indonesia mencanangkan Gerakan Nasional Pembangunan Karakter Bangsa. (Samani, 2011). 
Pusat Kurikulum Badan Penelitian dan Pengembangan Kementerian Pendidikan Nasional dalam Pedoman Pelaksanaan Pendidikan Karakter (2011) menyatakan bahwa pendidikan karakter bertujuan membentuk bangsa yang tangguh, kompetitif, berakhlak mulia, bermoral, bertoleran, bergotong royong, berjiwa patriotik, berkembang dinamis, berorientasi ilmu pengetahuan dan teknologi yang semuanya dijiwai oleh iman dan takwa kepada Tuhan Yang Maha Esa. Pendidikan karakter ini harus berlangsung baik dalam pendidikan formal (PAUD, SD/MI, SMP/MTs, SMA/SMK/MA dan perguruan tinggi), pendidikan nonformal maupun pendidikan informal di keluarga.

Meskipun pendidikan karakter telah menjadi perhatian bersama, namun termasuk narkoba. la menyebutkan, jumlahnya cukup lumayan yaitu selama 2017 sekitar 22 kasus anak yang menjadi kurir narkoba. Kemudian di tahun yang sama ada sekitar 46 anak yang menjadi korban penyalahgunaan narkoba. Sedangkan Afifah (2019) menyebutkan bahwa Ketua KPAI Susanto mengatakan, di tahun 2018, kasus anak berhadapan dengan hukum menduduki urutan pertama, yakni 1.434 kasus, kemudian disusul kasus terkait keluarga dan pengasuhan anak sebanyak 857 kasus.

Puspitawati \& Sarma (2012) menyatakan bahwa untuk memecahkan persoalan kualitas sumber daya manusia di negeri ini khususnya terkait kualitas anak, diperlukan pendekatan holistik yang menggabungkan sistem keluarga dan pendidikan. Kondisi keluarga sangat

\begin{tabular}{|c|c|c|c|}
\hline & Rumah & Sekolah & Masyarakat \\
\hline $\begin{array}{l}\text { Pembijaksanaan } \\
\text { usia tua }\end{array}$ & $\begin{array}{l}\text { Meningkatnya } \\
\text { pendekatan spiritual }\end{array}$ & $?$ & Banyak yang apatis \\
\hline Pemantapan usia dewasa & $?$ & ! & $\begin{array}{l}\text { - Low trust society } \\
\text { - Tidak saling } \\
\text { menghargai }\end{array}$ \\
\hline Pengembangan usia remaja & $?$ & $!$ & $\begin{array}{l}\text { - Tidak kondusif } \\
\text { - Orientasi pada uang, } \\
\text { materi dan duniawi }\end{array}$ \\
\hline Pembentukan usia dini & $\begin{array}{l}\text { Banyak diserahkan } \\
\text { pada pembantu }\end{array}$ & $!$ & Tidak kondusif \\
\hline
\end{tabular}

ternyata gambaran situasi masyarakat bahkan dunia pendidikan di Indonesia masih memprihatinkan. Kasus tawuran antar pelajar dan bentuk- bentuk kenakalan remaja lainnya, bullying, pergaulan bebas serta penggunaan narkoba makin meningkat. Kasus korupsi pun makin menggurita. Budaya disiplin, hidup bersih dan sehat serta menghargai lingkungan masih jauh dari standar.

Setiawan (2018) melaporkan bahwa Komisi Perlindungan Anak Indonesia (KPAl) mencatat banyaknya anak-anak Indonesia yang dijadikan kurir narkoba selama 2017. Anak-anak menjadi rentan karena Indonesia dijadikan sasaran empuk peredaran narkoba. Komisioner Komisi Perlindungan Anak Indonesia (KPAI) Pusat, Putu Elvina, mengatakan banyak kasus anak berhadapan dengan hukum tergantung lingkungan sekitarnya, dan sebaliknya, bahwa keluarga juga memengaruhi lingkungan sekitarnya. Soedarsono dalam Samani (2011) menjelaskan bahwa sinergi antara rumah (keluarga), sekolah dan masyarakat dalam hal pendidikan karakter belum terwujud dengan baik sehingga belum berdampak secara multidimensi. Tabel 1. menggambarkan potret membangun karakter yang masih terabaikan.

Tabel 1. Potret membangun karakter yang terabaikan

Keterangan: $?=$ dipertanyakan ! = perlu perhatian

Sumber: (Soedarsono dalam Samani, 2011) 
Jurnal Edumaspul, 4 (1), Year 2020 - 144

(Masduki Asbari, Wakhida Nurhayati, Agus Purwanto' Firdaus Putra)

Keluarga merupakan unit terkecil dalam masyarakat yang menjadi pilar penyangga eksistensi suatu bangsa. Institusi keluarga menjadi pusat kegiatan penting dari berbagai aspek kehidupan. Di dalamnya ada seorang pemimpin keluarga yang biasanya dilekatkan dengan lakilaki (kepala keluarga), manajer rumah tangga yang biasanya dilekatkan dengan perempuan (ibu rumah tangga), dan anak-anak yang memiliki hak mendapatkan pendidikan dan pengajaran baik karakter, keagamaan maupun sosial budaya. Pentingnya peranan keluarga karena keluarga menjadi sekolah yang pertama dan utama bagi anak-anak.

Pelaksanaan pendidikan keluarga memiliki landasan hukum yang kuat di Indonesia. Dalam Undang-Undang Republik Indonesia Nomor 20 Tahun 2003 tentang Sistem Pendidikan Nasional dinyatakan bahwa satuan pendidikan adalah kelompok layanan pendidikan yang menyelenggarakan pendidikan pada jalur formal, nonformal dan informal pada setiap jenjang dan jenis pendidikan. Pendidikan informal adalah jalur pendidikan keluarga dan lingkungan. Peraturan Pemerintah Nomor 21 Tahun 1994 (BKKBN, 1996) menyatakan adanya delapan fungsi yang harus dijalankan oleh keluarga meliputi fungsi-fungsi pemenuhan kebutuhan fisik dan nonfisik yang terdiri atas: keagamaan; sosial; budaya; cinta kasih; perlindungan; reproduksi; sosialisasi dan pendidikan; ekonomi; pembinaan lingkungan. Amanat Undang-Undang Nomor Tahun 2009 tentang perkembangan kependudukan dan pembangunan keluarga yang bertujuan untuk meningkatkan kualitas keluarga agar timbul rasa aman, tenteram, dan harapan masa depan yang lebih baik dalam mewujudkan kesejahteraan lahir dan kebahagiaan batin. Bahkan, Menteri Pendidikan dan Kebudayaan Republik Indonesia membentuk satuan kerja baru setingkat eselon II, yaitu Direktorat Pembinaan Pendidikan Keluarga. Tugas Direktorat tersebut diatur dalam Peraturan Pemerintah Nomor 11 Tahun 2015 yakni melaksanakan penyiapan perumusan dan pelaksanaan kebijakan di bidang pembinaan pendidikan keluarga.
Keberhasilan pendidikan di keluarga tidak lepas dari peran orang tua. Interaksi di tahun-tahun awal dengan orang tua memberikan pengaruh menetap dan jangka panjang pada kematangan perkembangan dan kesuksesan pendidikan anak khususnya terkait karakter. Maka pola pengasuhan orang tua (parenting) menjadi hal yang perlu dipelajari dan dikembangkan secara terusmenerus. Hasil penelitian Oktafiany (2013) menyatakan bahwa ada korelasi antara pola parenting dan kecerdasan emosi anak. Misbach (2010) menyatakan bahwa selain dipengaruhi oleh pola parenting, karakter yang nampak pada anak juga dipengaruhi oleh faktor genetika. Hal tersebut dikuatkan oleh pendapat Poniman (2012) bahwa fenotipe dipengaruhi oleh genetik dan lingkungan. Genetik ada yang bersifat hereditas (warisan dan ada yang bersifat non hereditas (given). Genetic personality adalah sifat bawaan (nature/genetic) non hereditas dan merupakan struktur genetis yang merupakan cetak biru (blue print) kekuatan dan kelemahan seseorang serta menjadi "kode" tiap individu.

Pengembangan karakter anak di Aya Sophia Islamic School dilakukan dengan mempertimbangkan faktor-faktor yang mempengaruhi karakter baik faktor genetika maupun faktor lingkungan. Jenis genetic personality anak diidentifikasi di awal tahun ajaran. Program parenting dilakukan dengan harapan pola asuh yang diterapkan oleh orang tua di rumah bisa selaras dengan kondisi lingkungan sekolah. Namun belum diketahui apakah ada hubungan antara identifikasi genetic personality dan pola asuh dengan pengembangan karakter anak di Aya Sophia Islamic School.

Berdasarkan uraian di atas, maka penting dilakukan penelitian dalam rangka mengkaji lebih dalam mengenai hubungan pengembangan karakter anak dengan pola asuh orang tua (parenting style) dan genetic personality. Hasil penelitian akan menjadi bahan evaluasi bagi program pengembangan karakter anak di Aya Sophia Islamic School. 
Kajian mengenai faktor-faktor tersebut juga diharapkan memberikan pengayaan mengenai pendidikan karakter di keluarga. Selain itu, masih terdapat celah dalam penelitian-penelitian sebelumnya yang membahas mengenai hubungan pola asuh (parenting style) dan genetic personality secara satu kesatuan terhadap pengembangan karakter anak.

\section{Penelitian yang Relevan}

Berdasarkan kajian kepustakaan yang dilakukan, beberapa hasil penelitian yang berkaitan dengan penelitian ini, di antaranya sebagai berikut:

1. Penelitian Rose M.E. Huver et.al. dengan judul Kepribadian dan Pola Asuh Remaja (Personality and Parenting Style in Parents of Adolescents). Penelitian ini dilakukan pada tahun 2010 terhadap keluarga di Netherland. Hasil penelitian menunjukkan bahwa pola asuh berpengaruh terhadap perkembangan kepribadian remaja (Huver, et al., 2010).

2. Penelitian Kingsley Nyarko dengan judul: Hubungan Pola Asuh Autoritative dan Motivasi Akademik Remaja (Authoritative Parenting Style on Adolescents Academic Achievement). Penelitian ini dilakukan pada tahun 2011 dengan pendekatan kuantitatif. Komponen yang digunakan untuk mengukur variabel authoritative parenting style meliputi penerimaan/dukungan orang tua terhadap anak, pengawasan/kontrol orang tua terhadap anak dan aspek kejiwaan orang tua. Hasil penelitian menunjukkan bahwa ada hubungan positif dan signifikan antara authoritative parenting dan motivasi belajar anak (Nyarko, 2011).

3. Penelitian Johari Talib dkk dengan judul: Dampak Pola Asuh pada Perkembangan Anak (Effects of Parenting Style on Children Development). Penelitian ini dilakukan pada tahun 2011 terhadap 200 keluarga dengan pendekatan kuantitatif. Hasil penelitian menunjukkan bahwa authoritative style berpengaruh positif terhadap sikap dan motivasi belajar anak (Talib et al., 2011).

4. Penelitian Jolita Jonyniene dan Roy M. Kern dengan judul: Gaya Hidup Psikologi dan Pola Asuh pada Orang Tua di Lithuanian (Individual Psychology Lifestyles and Parenting Style in Lithuanian Parents of 6-12 years old). Penelitian ini dilakukan pada tahun 2012 dan menunjukkan hasil bahwa authoritative parenting dilakukan oleh orang tua yang memiliki sikap optimis, fokus pada solusi, tingkat stres rendah, bertanggung jawab dan kooperatif (Jonyniene \& Kern, 2012).

5. Penelitian Nur Dian Oktafiany dkk dengan judul: Hubungan Parenting terhadap Kecerdasan Emosi Siswa SMP Diponegoro 1 Jakarta (Correlation of Parenting Method to the Student's Emotional Quotients of Diponegoro 1 Jakarta Junior High School). Penelitian ini dilakukan pada tahun 2013 dengan responden siswasiswi SMP Diponegoro 1 Jakarta. Pendekatan yang digunakan adalah kuantitatif. Hasil penelitian menunjukkan bahwa ada korelasi positif antara pola asuh/parenting dan kecerdasan emosi anak, dan pola parenting terbaik adalah demokratis (Oktaviany dkk, 2013).

6. Penelitian Nooraini Othman dan Salasiah Khairollah dengan judul: Hubungan Kepribadian Islam dan Pola Asuh (Exploring the Relationship between Islamic Personality and Parenting Style). Penelitian ini dilakukan pada tahun 2013 menggunakan pendekatan kuantitatif. Hasil penelitian menunjukkan bahwa terdapat hubungan positif dan signifikan antara gaya parenting authoritative dengan personaliti Islami yang meliputi ibadah, amanah dan ilmu (Othman \& Khairollah, 2013).

7. Penelitian Bushra Faraz Hasnain dan Parul Adlakha dengan judul: Hubungan Harga Diri dan Kebahagiaan Anak dengan Pola Asuh lbu) Self Esteem and Happiness of Children and Mothers of Different Parental Authority. Penelitian ini dilakukan pada 
tahun 2013. Hasil penelitian menunjukkan bahwa parenting style berpengaruh terhadap harga diri dan kebahagiaan anak. Melalui analisa one-way ANOVA dan Turkey Test diketahui bahwa anak-anak dengan pola parenting authoritative memiliki harga diri dan kebahagiaan lebih tinggi dibandingkan anak-anak dengan pola parenting authoritarian dan permissive (Hasnain \& Adlakha, 2013).

8. Penelitian Dailinar Utomo dengan judul: Intensi Perilaku Prososial Anak ditinjau dari Gaya Pengasuhan. Penelitian dilakukan pada tahun 2014 dan hasilnya menunjukkan bahwa ada korelasi positif antara gaya pengasuhan dengan perilaku prososial anak (Utomo, 2014).

9. Penelitian MM. Shinta Pratiwi dengan judul: Kecerdasan Moral Anak Usia Prasekolah Etnis Cina ditinjau dari Gaya Pengasuhan Orangtua. Penelitian ini dilakukan pada tahun 2015 dengan pendekatan kuantitatif. Hasil penelitian menunjukkan bahwa kecerdasan moral anak yang mendapat gaya pengasuhan authoritative lebih tinggi dibanding dengan gaya pengasuhan authoritarian, permissive dan uninvolved (neglectful) (Pratiwi, 2015).

\section{Kerangka Pemikiran dan Hipotesis}

Variabel dalam penelitian ini terdiri dari dua variabel bebas yaitu parenting style (X1) dan genetic personality (X2) serta variabel terikat yaitu pengembangan karakter anak (Y). Berdasarkan kajian pustaka dan penelitian-penelitian yang dilakukan sebelumnya, maka dikembangkan model penelitian yang menggambarkan hubungan antar variable. Adapun hubungan antar variabel pada model penelitian ini dan dasar teorinya dijelaskan sebagai berikut:

1. Pengaruh parenting style terhadap pengembangan karakter anak

Ada pengaruh antara pendidikan di keluarga dengan pengembangan karakter anak-anaknya. Keluarga merupakan landasan unit kerja sama sosial dengan melibatkan orang tua, ayah dan ibu, untuk bekerja bersama dalam mendidik anak-anaknya (Coleman dalam Puspitawati, 2012). Huver et al. (2010) menyatakan bahwa parenting style mempengaruhi personality remaja. Puspitawati dan Sarma (2012) dalam penelitiannya menjelaskan bahwa ada korelasi antara pengasuhan dengan kemampuan kontrol diri anak. Dengan kata lain dinyatakan bahwa perilaku anak dipengaruhi oleh perlakuan orang tua terhadap dirinya. Hasil penelitian Abidin (2011) juga menunjukkan bahwa gaya pengasuhan yang didasari atas kasih sayang dan penerimaan positif yang tinggi, tidak diabaikan, tidak diserang dan tidak ditolak, berpengaruh positif terhadap perilaku sosial anak. Hal ini berarti bahwa orang tua yang menerapkan gaya pengasuhan yang baik akan menjadikan perilaku sosial anak semakin baik. Hal ini sejalan juga dengan hasil penelitian Oktafiany dkk (2013) bahwa ada korelasi positif antara pola asuh/parenting dan kecerdasan emosi anak. Dijelaskan lebih lanjut bahwa pola asuh terbaik adalah demokratis. Berdasarkan penjelasan di atas maka diduga bahwa parenting style berhubungan dengan pengembangan karakter anak di Aya Sophia Islamic School.

\section{Pengaruh genetic personality terhadap pengembangan karakter anak}

Dalam konteks nature, karakter seseorang dipengaruhi oleh struktur genetis yang merupakan cetak biru (blue print) kekuatan dan kelemahan seseorang serta menjadi "kode" tiap individu yang bersifat tetap (Misbach, 2010). Genetic personality merupakan karakter bawaan yang berkaitan dengan dominasi sistem kerja otak. Genetic personality dapat diketahui dengan metode biometri dan metode yang digunakan dalam penelitian ini adalah STIFIn fingerprint analysis. Poniman (2012) menyatakan bahwa fenotipe dipengaruhi oleh faktor genotipe dan lingkungan. Salah satu 
faktor genotipe yang menentukan adalah genetic personality.

Berdasarkan penjelasan di atas, maka diduga bahwa genetic personality berpengaruh terhadap pengembangan karakter anak di Aya Sophia Islamic School.

Adapun model penelitian ini bisa diilustrasikan sebagai berikut:

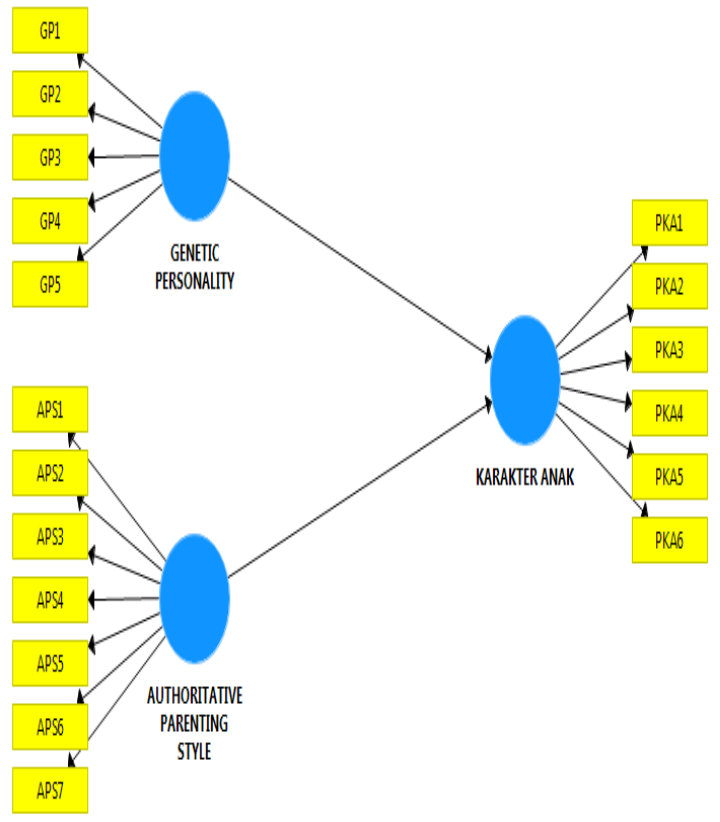

Gambar 1. Model Penelitian

Data internal hasil olahan SmartPLS 3.0

Berdasarkan model penelitian yang telah dirancang, maka rumusan hipotesis yang diajukan pada penelitian ini adalah:

$\mathrm{H} 1$ : Genetic personality berpengaruh positif dan signifikan terhadap pengembangan karakter anak di Aya Sophia Islamic School.

H2: Authoritative Parenting style berpengaruh positif dan signifikan terhadap pengembangan karakter anak di Aya Sophia Islamic School.

\section{Tujuan Penelitian}

Tujuan penelitian ini untuk mengetahui pengaruh parenting style dan genetic personality terhadap pengembangan karakter anak di Aya Sophia Islamic
School. Berdasarkan rumusan masalah dan hipotesis penelitian, maka tujuan penelitian secara rinci dirumuskan sebagai berikut:

1. Mengetahui pengaruh genetic personality (X1) terhadap pengembangan karakter anak di Aya Sophia Islamic School (Y).

2. Mengetahui pengaruh authoritative parenting style (X2) terhadap pengembangan karakter anak di Aya Sophia Islamic School (Y).

\section{METODOLOGI}

Metode yang digunakan dalam penelitian ini adalah metode survei dengan pendekatan penelitian korelasional. Dilakukan pengumpulan data dengan mengedarkan angket kepada orang tua siswa Aya Sophia Islamic School. Instrumen yang digunakan untuk mengukur pola asuh (parenting style) merupakan hasil modifikasi dari Parenting Style Questionnaire (PSQ) Robinson et al. (1995) dan Roman et al. (2015). Instrumen untuk mengukur genetic personality diadaptasi dari Poniman \& Mangussara (2013), sedangkan untuk mengukur pengembangan karakter anak menggunakan adaptasi dari Poniman dkk. (2014). Angket didesain tertutup kecuali untuk pertanyaan/pernyataan mengenai identitas responden yang berupa angket semi terbuka. Tiap item pertanyaan/pernyataan tertutup diberikan lima opsi jawaban, yaitu: sangat setuju (SS) skor 5, setuju (S) skor 4, kurang setuju (KS) skor 3, tidak setuju (TS) skor 2, dan sangat tidak setuju (STS) skor 1.

\section{Populasi dan Sampel}

Populasi penelitian ini adalah orang tua siswa Aya Sophia Islamic School sebanyak 184 orang. Kuesioner yang kembali dan valid sebanyak 144 sampel. Kuesioner (angket) yang disusun berdasarkan skala Likert. Penelitian dilakukan terhadap orang tua yang telah mengetahui jenis genetic personality anaknya melalui STIFIn fingerprint 
Jurnal Edumaspul, 4 (1), Year 2020 - 148

(Masduki Asbari, Wakhida Nurhayati, Agus Purwanto' Firdaus Putra)

analysis dan terlibat dalam pengasuhan anaknya.

\section{Metode Analisis Data}

Metode untuk menganalisis data adalah dengan menggunakan software SmartPLS versi 3.0. Ghozali (2014) menjelaskan bahwa PLS adalah metode analisis yang bersifat soft modeling karena tidak mengasumsikan data harus dengan pengukuran skala tertentu, yang berarti jumlah sampel dapat kecil (di bawah 100 sampel).

\section{HASIL DAN PEMBAHASAN}

\section{Deskripsi Sampel}

Tabel 2. Informasi Deskriptif Sampel

\begin{tabular}{|c|c|c|c|}
\hline \multicolumn{2}{|c|}{ Kriteria } & $\underset{h}{\text { Jumla }}$ & $\begin{array}{c}\text { Persenta } \\
\text { si }\end{array}$ \\
\hline \multirow{2}{*}{$\begin{array}{l}\text { Usia } \\
\text { Pasanga } \\
\mathrm{n} \\
\text { Orangtua }\end{array}$} & $\begin{array}{l}<40 \\
\text { tahun }\end{array}$ & 98 & $68,06 \%$ \\
\hline & $\begin{array}{l}\geq \quad 40 \\
\text { tahun }\end{array}$ & 46 & $31,94 \%$ \\
\hline \multirow{2}{*}{$\begin{array}{l}\text { Pendidika } \\
\text { n } \\
\text { Pasanga } \\
\text { n } \\
\text { Orangtua }\end{array}$} & $\begin{array}{l}\text { Sarjan } \\
\text { a }\end{array}$ & 102 & $70,83 \%$ \\
\hline & $\begin{array}{l}\text { Belum } \\
\text { Sarjan } \\
\text { a }\end{array}$ & 42 & $29,17 \%$ \\
\hline \multirow{5}{*}{$\begin{array}{l}\text { Tipologi } \\
\text { Genetic } \\
\text { personalit } \\
\text { y Siswa }\end{array}$} & $\begin{array}{l}\text { Thinkin } \\
\mathrm{g}\end{array}$ & 39 & $27,08 \%$ \\
\hline & Sening & 35 & $24,31 \%$ \\
\hline & Feeling & 32 & $22,22 \%$ \\
\hline & $\begin{array}{l}\text { Intuitin } \\
\mathrm{g}\end{array}$ & 24 & $16,67 \%$ \\
\hline & Instinct & 14 & $9,72 \%$ \\
\hline
\end{tabular}

Sumber: Data internal yang diolah

\section{Pengujian Outer Model}

Tahap pengujian model pengukuran meliputi pengujian Convergent Validity, Discriminant Validity dan Composite Reliability. Hasil analisis PLS dapat digunakan untuk menguji hipotesis penelitian jika seluruh indikator dalam model PLS telah memenuhi syarat validitas konvergen, validitas deskriminan dan reliabilitas komposit.

\section{Pengujian Validitas Konvergen}

Uji validitas konvergen dilakukan dengan melihat nilai loading factor masing-masing indikator terhadap konstruknya. Untuk penelitian konfirmatori, batas loading factor yang digunakan adalah sebesar 0,7, sedangkan untuk penelitian eksploratori maka batas loading factor yang digunakan adalah sebesar 0,6 dan untuk penelitian pengembangan, batas loading factor yang digunakan adalah 0,5 (Ghozali, 2014). Oleh karena penelitian ini merupakan penelitian konfirmatori, maka batas loading factor yang digunakan adalah sebesar 0,7. Berikut ini adalah hasil estimasi model PLS:

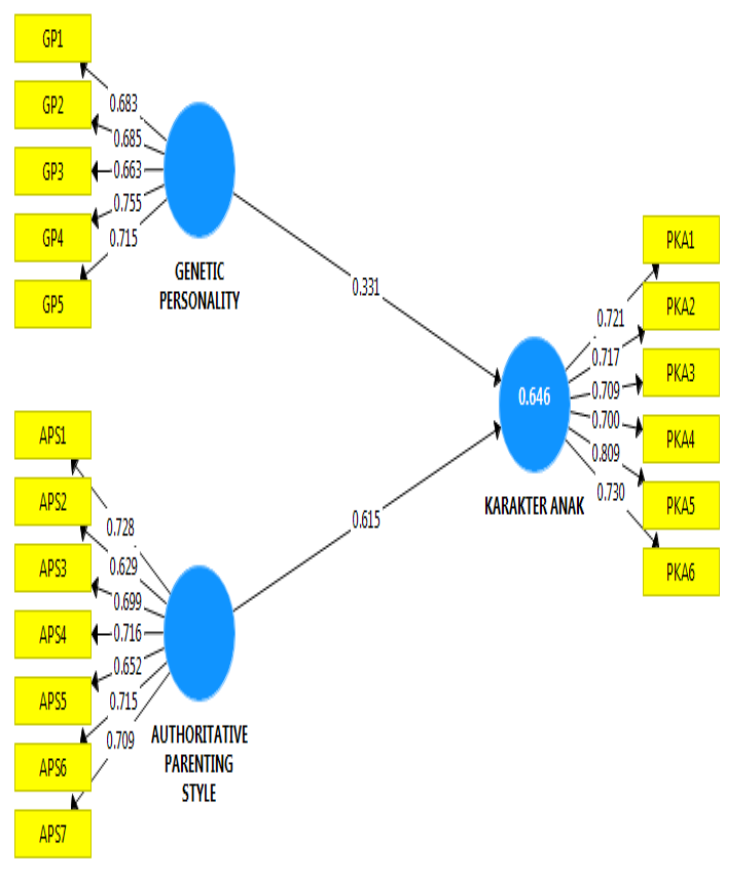

Gambar 2 . Estimasi Model PLS Model Pengukuran

Data internal hasil olahan SmartPLS 3.0

Berdasarkan hasil analisis pada gambar di atas, dapat dilihat beberapa indikator memiliki loading factor di bawah 0,7 sehingga dinyatakan tidak valid dan harus 
Jurnal Edumaspul, 4 (1), Year 2020 - 149

(Masduki Asbari, Wakhida Nurhayati, Agus Purwanto' Firdaus Putra)

didrop dari model, hasil estimasi model setelah indikator tidak valid didrop dari model adalah sebagai berikut:

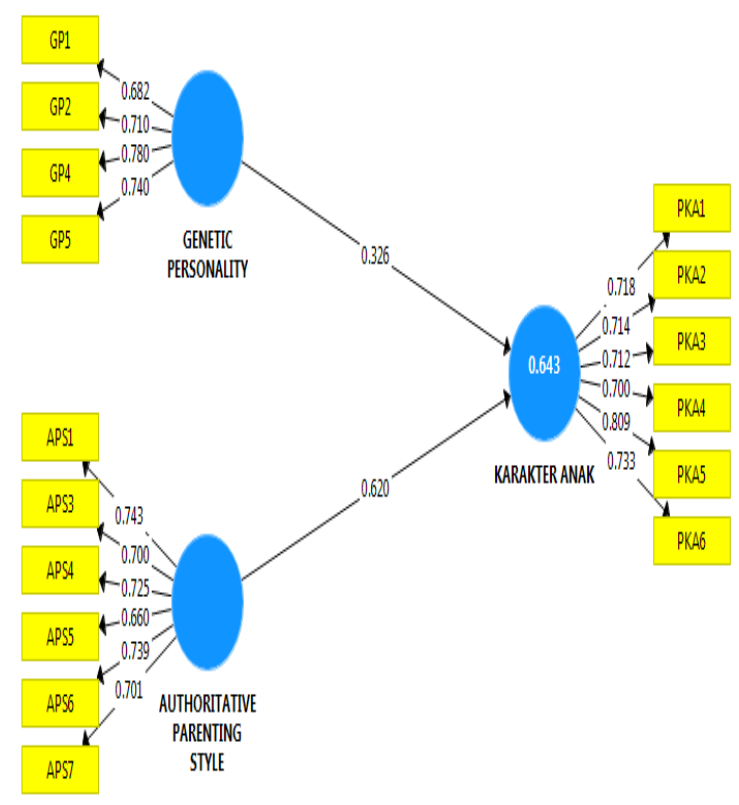

Gambar 3 . Estimasi Model PLS Model Valid

Data internal hasil olahan SmartPLS 3.0

Berdasarkan hasil estimasi model PLS pada gambar di atas, seluruh indikator telah memiliki nilai loading factor di atas 0,7 sehingga model telah memenuhi syarat validitas konvergen. Selain dengan melihat nilai loading factor masing-masing indikator, validitas konvergen juga dinilai dari nilai AVE setiap konstruk, model PLS dinyatakan telah memenuhi validitas konvergen jika nilai AVE setiap konstruk > 0,5 (Ghozali, 2014). Nilai AVE setiap konstruk selengkapnya dapat dilihat pada tabel 4 berikut:

Tabel 2. Items Loadings, Cronbach's Alpha, Composite Reliability, and Average Variance Extracted (AVE)

\begin{tabular}{|c|c|c|c|c|c|}
\hline Varables & Items & Loadings & $\begin{array}{c}\text { Cronbac } \\
\text { h's } \\
\text { Alpha }\end{array}$ & $\begin{array}{c}\text { Composi } \\
\text { te } \\
\text { Reliabilit } \\
y\end{array}$ & AVE \\
\hline \multirow{3}{*}{$\begin{array}{c}\text { Genetic } \\
\text { Personalit } \\
y \\
(G P)\end{array}$} & GP1 & 0.682 & 0.711 & 0.819 & $\begin{array}{c}0.53 \\
2\end{array}$ \\
\hline & GP2 & 0.710 & & & \\
\hline & GP4 & 0.780 & & & \\
\hline
\end{tabular}

\begin{tabular}{|c|c|c|c|c|c|}
\hline & GP5 & 0.740 & & & \\
\hline $\begin{array}{c}\text { Authoritati } \\
\text { ve } \\
\text { Parenting }\end{array}$ & $\begin{array}{c}\text { APS } \\
1\end{array}$ & 0.743 & 0.805 & 0.860 & $\begin{array}{c}0.50 \\
7\end{array}$ \\
\hline $\begin{array}{l}\text { Style } \\
\text { (APS) }\end{array}$ & $\begin{array}{c}\text { APS } \\
3 \\
\text { APS } \\
4 \\
\text { APS } \\
5 \\
\text { APS } \\
6 \\
\text { APS } \\
7\end{array}$ & $\begin{array}{l}0.700 \\
0.725 \\
0.660 \\
0.739 \\
0.701\end{array}$ & & & \\
\hline $\begin{array}{c}\text { Karakter } \\
\text { Anak }\end{array}$ & $\begin{array}{c}\text { PKA } \\
1\end{array}$ & 0.718 & 0.833 & 0.873 & $\begin{array}{c}0.53 \\
5\end{array}$ \\
\hline (PKA) & $\begin{array}{c}\text { PKA } \\
2 \\
\text { PKA } \\
3 \\
\text { PKA } \\
4 \\
\text { PKA } \\
5 \\
\text { PKA } \\
6\end{array}$ & $\begin{array}{l}0.714 \\
0.712 \\
0.700 \\
0.809 \\
0.733\end{array}$ & & & \\
\hline
\end{tabular}

Sumber: Data internal hasil olahan SmartPLS 3.0

Berdasarkan hasil analisis PLS pada tabel di atas, nilai AVE seluruh konstruk baik yang berupa dimensi maupun variabel telah melebihi 0,5 yang menunjukkan bahwa seluruh indikator pada masingmasing konstruk telah memenuhi kriteria validitas konvergen yang disyaratkan.

\section{Pengujian Validitas Deskriminan}

Discriminant validity dilakukan untuk memastikan bahwa setiap konsep dari masing-masing variabel laten berbeda dengan variabel lainnya. Model mempunyai discriminant validity yang baik jika nilai kuadrat AVE masing-masing konstruk eksogen (nilai pada diagonal) melebihi korelasi antara konstruk tersebut dengan konstruk lainnya (nilai di bawah diagonal) (Ghozali, 2014). Hasil pengujian discriminant validity diperoleh sebagai berikut:

Tabel 3. Discriminant Validity

\begin{tabular}{cccc}
\hline VARIABLES & APS & GP & PKA \\
\hline APS & $\mathbf{0 . 7 1 2}$ & & \\
GP & 0.376 & $\mathbf{0 . 7 2 9}$ & \\
PKA & 0.743 & 0.559 & $\mathbf{0 . 7 3 2}$ \\
\hline
\end{tabular}

Sumber: Data internal hasil olahan SmartPLS 3.0 
Jurnal Edumaspul, 4 (1), Year 2020 - 150

(Masduki Asbari, Wakhida Nurhayati, Agus Purwanto' Firdaus Putra)

Hasil uji validitas deskriminan pada tabel di atas menunjukkan bahwa seluruh konstruk telah memiliki nilai akar kuadrat AVE di atas nilai korelasi dengan konstruk laten lainnya sehingga dapat disimpulkan bahwa model telah memenuhi validitas deskriminan.

\section{Pengujian Reliabilitas Komposit}

Reliabilitas konstruk dapat dinilai dari nilai crombachs Alpha dan nilai Composite Reliability dari masing-masing konstruk. Nilai composite reliability dan cronbachs alpha yang disarankan adalah lebih dari 0,7 . Namun demikian, pada penelitian pengembangan, oleh karena batas loading factor yang digunakan rendah $(0,5)$, maka nilai composite reliability dan cronbachs alpha rendah masih dapat diterima selama persyaratan validitas konvergen dan validitas deskriminan telah terpenuhi (Ghozali, 2014). Hasil uji reliabilitas pada tabel di atas menunjukkan bahwa seluruh konstruk telah memiliki nilai composite reliability dan cronbachs alpha $>0,7$. Kesimpulannya, seluruh konstruk telah memenuhi reliabilitas yang disyaratkan.

\section{Pengujian Inner Model}

Pengujian inner model meliputi uji signifikansi pengaruh langsung dan pengukuran besarnya pengaruh variabel eksogen terhadap variabel endogen. Dengan teknik boothstrapping, diperoleh nilai $R$ Square dan nilai uji signifikansi dan sebagaimana tabel di bawah ini:

Tabel 4. Nilai $R$ Square

\begin{tabular}{ccc}
\hline & R Square & $\begin{array}{c}\text { R Square } \\
\text { Adjusted }\end{array}$ \\
\hline PKA & 0.643 & 0.638 \\
\hline
\end{tabular}

Tabel 5. Hypotheses Testing
Berdasarkan table 4 di atas, nilai $\mathrm{R}$ Square sebesar 0,643 yang berarti bahwa variabel pengembangan karakter anak mampu dijelaskan variabel genetic personality dan authoritative parenting style sebesar $64,3 \%$, sedangkan sisanya sebesar $35,7 \%$ dijelaskan oleh variabel lain yang tidak dibahas dalam penelitian ini. Dari tabel 5 di atas dapat disimpulkan temuan penelitian sebagai mana penjelasan di bawah ini:

\section{Pengaruh genetic personality terhadap pengembangan karakter anak}

Temuan penelitian menunjukkan bahwa genetic personality memberikan pengaruh positif dan signifikan terhadap pengembangan karakter anak di Aya Sophia Islamic School. Hal ini dibuktikan dengan nilai $p$ values sebesar 0,000 yang lebih kecil dari 0,05 . Nilai $T$ Statistic sebesar 6,685 yang lebih besar dari 1,96. Nilai original sample 0,326 yang bernilai positif. Jadi, kesimpulannya hipotesis $\mathrm{H} 1$ diterima.

Temuan penelitian ini menguatkan penelitian Dryden dan Vos dalam Musrofi (2011) yang menyatakan bahwa setiap anak secara potensial memiliki karakter yang unik. Hal tersebut sesuai dengan pendapat Murakami (2013) yang menyatakan bahwa setiap orang itu unik. Tidak ada dua set gen yang persis sama, tidak ada dua orang yang persis sama. Perbedaan tiap orang tidak hanya terwujud pada wajah atau penampilan, tetapi juga pada sifat dan kemampuan. Misbach (2010) menguatkan pendapat di atas bahwa dalam konteks nature, karakter seseorang dipengaruhi oleh struktur genetis yang merupakan cetak biru (blue print) kekuatan dan kelemahan seseorang serta menjadi "kode" tiap individu yang bersifat tetap. Poniman

\begin{tabular}{ccccccc}
\hline $\begin{array}{c}\text { Hypothese } \\
\text { s }\end{array}$ & Relationship & Beta & SE & T Statistics & V-Values & Decision \\
\hline H1 & GP -> PKA & 0.326 & 0.049 & 6.685 & 0.000 & Supported \\
H2 & APS -> PKA & 0.620 & 0.054 & 11.524 & 0.000 & Supported
\end{tabular}

Sumber: Data internal hasil olahan SmartPLS 3.0
(2012) menyatakan bahwa fenotipe dipengaruhi oleh faktor genotipe dan lingkungan. Salah satu faktor genotipe yang menentukan adalah genetic 
Jurnal Edumaspul, 4 (1), Year 2020 - 151

(Masduki Asbari, Wakhida Nurhayati, Agus Purwanto' Firdaus Putra)

personality, yaitu karakter bawaan yang berkaitan dengan dominasi sistem kerja otak. Hasil analisis data menunjukkan bahwa genetic personality anak di Aya Sophia Islamic School didominasi oleh thinking sebesar 29,17\%, kemudian sensing $24,31 \%$, feeling dan intuiting masing-masing $22,22 \%$ dan $16,67 \%$ serta insting $9,72 \%$. Berdasarkan hasil penelitian ini maka semestinya pengembangan karakter anak di sekolah khususnya di lembaga pendidikan memperhatikan juga faktor genetic personality anak. Identifikasi genetic personality dapat dilakukan di awal tahun ajaran dan sekolah dapat menjalin kerja sama dengan lembaga psikologi atau lembaga pengembangan sumber daya manusia yang terjangkau.

Temuan dalam penelitian ini juga sejalan dengan hasil penelitian neuroscience yang menyatakan bahwa ada hubungan yang sangat erat antara kondisi psikologis seseorang dan sistem kerja struktur otaknya. Sementara itu perkembangan ilmu dermatoglypics dan dactiloscopy-ilmu penelitian terkait struktur sidik jarimemberikan gambaran adanya hubungan struktur biologis dalam hal ini sidik jari dengan sistem kerja otak sehingga dapat diungkapkan kaitan pola sidik jari dengan interdisipliner berbagai bidang ilmu termasuk psikologi dan pendidikan. Dr. Mary Lai, Ph.D., MME dari Taiwan adalah salah satu pendidik yang menggunakan manfaat sidik jari dan penelitian dermatoglyphics dalam konseling orang tua (Misbach, 2010).

Hasil penelitian ini sesuai juga dengan pendapat Poniman (2012) bahwa fenotipe dipengaruhi oleh faktor genotipe dan lingkungan. Dalam hal ini, karakter merupakan fenotipe, parenting style merupakan bagian dari faktor lingkungan, sedangkan genetic personality adalah bagian dari faktor genotipe. Murakami (2012) menyatakan bahwa setiap gen mengandung informasi yang sangat banyak. Genetika sangat mempengaruhi perilaku suatu spesies, meskipun di sisi lain lingkungan juga dipercaya memainkan peranan penting. Penelitian tentang keterkaitan genetik terhadap watak/karakter masih terus dilakukan hingga saat ini.

Hasil penelitian ini menguatkan beberapa penelitian sebelumnya, salah satunya adalah penelitian yang dilakukan oleh Ferguson (2010) dengan judul Kontribusi Genetika terhadap Karakter dan Perilaku Antisosial: Sebuah Meta-Analisis dari Perspektif Evolusi. Hasil penelitian tersebut menyatakan bahwa genetika mempengaruhi karakter dan perilaku antisosial sebesar 56\%. Penelitian lain dilakukan oleh Miles dan Carey (1997) yang menyatakan bahwa faktor genetika dan lingkungan mempengaruhi perilaku agresi anak sebesar masing-masing 50\%. Faktor lingkungan yang berpengaruh cukup kuat adalah lingkungan keluarga. Sementara itu Carey dan Dilalla (1994) menyatakan bahwa faktor genetika mempengaruhi karakter dengan prosentase antara $30 \%$ hingga $60 \%$.

2. Pengaruh authoritative parenting style terhadap pengembangan karakter anak

Temuan penelitian menunjukkan bahwa parenting style memberikan pengaruh positif dan signifikan terhadap pengembangan karakter anak di Aya Sophia Islamic School. Hal ini dibuktikan dengan nilai $p$ values sebesar 0,000 yang lebih kecil dari 0,05 . Nilai $T$ Statistic sebesar 11,524 yang lebih besar dari 1,96. Nilai original sample 0,620 yang bernilai positif. Jadi, kesimpulannya hipotesis $\mathrm{H} 2$ diterima.

Temuan penelitian ini sejalan dengan Teori Ekologi Bronfenbrenner yang menyatakan bahwa perkembangan anak dipengaruhi oleh lima sistem lingkungan yang merentang dari interaksi interpersonal sampai ke pengaruh kultur yang lebih luas. Bronfenbrenner menyebut sistemsistem itu sebagai mikrosistem, mesosistem, eksosistem, makrosistem dan kronosistem. Pada anak usia dini, yang paling dominan berpengaruh adalah mikrosistem di mana anak menghabiskan banyak waktunya. Beberapa konteks dalam sistem ini antara lain adalah 
Jurnal Edumaspul, 4 (1), Year 2020 - 152

(Masduki Asbari, Wakhida Nurhayati, Agus Purwanto' Firdaus Putra)

keluarga, teman sebaya, sekolah dan tetangga (Santrock, 2008). Namun demikian, bukan berarti sistem lingkungan yang lain tidak memberikan kontribusi bagi perkembangan anak. Mesosistem yang merupakan kaitan antar-mikrosistem seperti pengalaman di keluarga dan sekolah; eksosistem yaitu kebijakan stake holder terkait perkembangan anak dan makrosistem seperti kultur masyarakat juga turut mempengaruhi perkembangan anak. Kondisi sosiohistoris (kronosistem) pun tidak bisa dipungkiri ikut berpengaruh, di mana anak-anak abad 21 adalah generasi $Z$ yang tidak terlepas dari pengaruh perkembangan media dan teknologi. Aziz (2012) menyatakan bahwa keluarga memegang peranan vital dalam pembentukan dan pengembangan karakter bagi setiap anggotanya, utamanya anak-anak.

Temuan dalam penelitian ini juga sejalan dengan hasil penelitian Rose M.E. Huver et al. yang menunjukkan bahwa parenting style berpengaruh terhadap perkembangan kepribadian anak (Huver, 2010). Selain itu sejalan juga dengan hasil penelitian Talib dkk yang menyatakan bahwa parenting style berpengaruh terhadap sikap anak (Talib, 2011) dan hasil penelitian Efobi pada tahun 2014 yang menunjukkan bahwa parenting style memberikan dampak bagi perkembangan anak (Efobi, 2014).

Berdasarkan hasil penelitian ini maka semestinya pengembangan karakter di sekolah khususnya di lembaga Pendidikan Anak Usia Dini melibatkan peran orang tua. Program pendidikan parenting dalam bentuk training dan workshop sebagai upaya menyelaraskan pola asuh di keluarga dan proses pembentukan karakter di sekolah perlu menjadi perhatian utama.

Berdasarkan hasil penelitian ini maka semestinya pengembangan karakter anak di sekolah khususnya di lembaga Pendidikan Anak Usia Dini memperhatikan secara bersama-sama antara faktor pola asuh keluarga (parenting style) genetic personality anak. Program edukasi tentang pengembangan karakter anak berdasarkan pola asuh dan genetic personality agar terus dilakukan baik kepada guru sebagai pendidik di lingkungan sekolah maupun orang tua sebagai pendidik di lingkungan keluarga.

Karakter yang dikembangkan di PAUD Aya Sophia Islamic School mengacu pada visi lembaga, yaitu berfokus pada karakter sholeh, cerdas dan mandiri. Tiga karakter tersebut juga sesuai dengan pedoman pendidikan karakter yang ditetapkan oleh Kementerian Pendidikan dan Kebudayaan tentang 18 nilai-nilai karakter yang perlu dikembangkan. Religius, jujur, toleransi, peduli lingkungan dan cinta damai tercakup dalam karakter sholeh. Sementara rasa ingin tahu, gemar membaca dan menghargai prestasi tercakup dalam karakter cerdas. Mandiri meliputi pula disiplin, kerja keras, peduli lingkungan dan tanggung jawab. Penyamaan persepsi antara pihak sekolah dan orang tua (keluarga) terkait karakter yang dikembangkan ini dilakukan secara intensif sejak awal tahun ajaran baru dengan harapan ada keselarasan antara lingkungan sekolah dan keluarga.

\section{KESIMPULAN}

Penelitian ini merupakan suatu survei yang dilakukan di Aya Sophia Islamic School Kabupaten Tangerang untuk memperoleh gambaran mengenai pengaruh parenting style dan genetic personality dengan pengembangan karakter anak. Berdasarkan hasil penelitian, dapat diambil kesimpulan sebagai berikut:

1. Parenting style memberikan pengaruh positif dan signifikan terhadap pengembangan karakter anak di Aya Sophia Islamic School. Artinya bahwa semakin positif pola asuh orang tua maka akan semakin baik pula proses pengembangan karakter anak.

2. Genetic personality memberikan 
pengaruh positif dan signifikan terhadap pengembangan karakter anak di Aya Sophia Islamic School. Artinya semakin baik identifikasi genetic personality maka akan semakin baik pula proses pengembangan karakter anak. Hasil analisis data menunjukkan bahwa genetic personality anak di PAUD Aya Sophia Islamic School didominasi oleh sensing sebesar $27,1 \%$, kemudian feeling $25,0 \%$, thinking dan intuiting masing-masing $20,8 \%$ serta insting $6,3 \%$.

\section{SARAN}

Berdasarkan hasil penelitian yang telah dilakukan, dikemukakan beberapa saran sebagai berikut:

\section{Bagi Sekolah}

Pengembangan karakter anak khususnya anak usia dini dipengaruhi oleh faktor pola asuh di keluarga dan genetic personality anak. Oleh karena itu, sekolah perlu mengembangkan secara serius program pendidikan parenting dalam rangka mengedukasi para orang tua sehingga mampu menerapkan pola asuh di keluarga yang tepat dan mendukung pengembangan karakter anak.

\section{Bagi Orang Tua}

Keluarga merupakan sekolah pertama dan utama bagi anak. Oleh karena itu, para orang tua semestinya tidak hanya menyerahkan proses pengembangan karakter anak kepada pihak sekolah semata. Namun orang tua juga menjadi pribadi pembelajar sehingga mampu bersinergi dengan pihak sekolah untuk bersama-sama memberikan peran terbaiknya dalam proses pengembangan karakter anak.

\section{Bagi Guru}

Guru merupakan pendidik di lingkungan sekolah yang turut mewarnai pengembangan karakter anak. Maka guru diharapkan memahami pola asuh yang terbaik bagi anak dan genetic personality siswa- siswinya sehingga dalam proses pembelajaran mampu memilih strategi yang beragam. Dengan demikian diharapkan proses pembelajaran menjadi satu bagian aktivitas yang menginspirasi anak- anak untuk tumbuh menjadi generasi yang berkarakter.

\section{REFERENCES}

Abidin, A.R. (2011). Analisis Gender pada Gaya Pengasuhan, Proses Pembelajaran di Kelas, Perilaku Sosial dan Prestasi Belajar Siswa SMA di Kota Bogor. Tesis. Sekolah Pascasarjana IPB. Bogor: IPB.

Afifah, A. (2019, Januari 8). Selama 2018, KPAI Terima Pengaduan 4.885 Kasus Anak. $<$ http://www.dakta.com/news/17920/sel ama-2018-kpai-terima-pengaduan4885-kasus-anak>. Diakses: 15 Oktober 2019.

Asbari. M.,Nurhayati. W.,Purwanto.A, (2020).The effect of parenting style and genetic personality on children character development. Jurnal Penelitian dan Evaluasi Pendidikan : 23(2).DOI:

https://dx.doi.org/10.21831/pep.v23i2.2 $\underline{8151}$

Asbari, M., Wijayanti,L.M, Hyun, C.C., Purwanto, A., Santoso, P.B,(2020).Effect of Tacit and Explicit Knowledge Sharing on Teacher Innovation Capability,Dinamika Pendidikan, $\quad$ 14(2),4759,https://doi.org/10.15294/dp.v14i2.22 732

Asbari, M., Nurhayati, W., \& Purwanto, A. (2019). Pengaruh Parenting style dan Personality Genetic Terhadap Pengembangan Karakter Anak di Paud Islamic School. JURNAL AUDI: Jurnal IImiah Kajian IImu Anak dan Media Informasi PAUD, 4(2), 148163.http://ejurnal.unisri.ac.id/index.php/i paud/article/view/3344

Asbari, M., Wijayanti, L., Hyun, C., Imelda, D., yanthy, E., \& PURWANTO, A. (2020). HARD SKILLS ATAU SOFT SKILLS: MANAKAH YANG LEBIH PENTING BAGI INOVASI GURU. Edumaspul: Jurnal Pendidikan, 4(1), 1-20. 
Jurnal Edumaspul, 4 (1), Year 2020 - 154

(Masduki Asbari, Wakhida Nurhayati, Agus Purwanto' Firdaus Putra)

https://doi.org/10.33487/edumaspul.v4i 1.333

Aziz, A. H. (2012). Pendidikan Karakter Berpusat pada Hati. Jakarta: Al Mawardi Prima.

BKKBN. (1996). Peraturan Pemerintah Nomor 21 Tahun 1994.

Carey, G. \& Dilalla, D. L. (1994). Personality and Psychopathology: Genetic Perspective. Journal of Abnormal Psychology, 103(1).

Efobi, A. \& Nwokolo, C. (2014). Relationship between Parenting Styles and Tendency to Bullying Behaviour among Adolescents. Journal of Education and Human Development, 3 (1).

Ferguson, C. (2010). Genetic Contributions to Antisocial Personality and Behavior: A Meta-Analytic Review from an Evolutionary Perspective. The Journal of Social Psychology, 150 (2).

Ghozali, I. (2014). Structural Equation Modeling, Metode Alternatif dengan Partial Least Square (PLS). Edisi 4. Semarang: Badan Penerbit Universitas Diponegoro.

Huver, R. M . E. et al. (2010). Personality and Parenting Style in Parents of Adolescents. Journal of Adolescence, 33.

Hasnain, B.F. \& Adlakha, A. (2013). Self Esteem and Happiness of Children and Mothers of Different Parental Authority. The International Journal of Humanities and Social Studies, 1.

Jonyniene, J. \& Kern, R.M. (2012). Individual Psychology Lifestyles and Parenting Style in Lithuanian Parents of 6 to 12 Years Old. International Journal of Psychology.

Miles, D. \& Carey, G. (1997). Genetic and Environmental Architecture of Human Aggression. Journal of Personality and Social Psychology, 27(1).

Mirayani, R., S.Williana Kusumaningsih, \& Anggaripeni Mustikasiwi. (2019). TRANSFORMATIONAL, AUTHENTIC, AND AUTHORITARIAN TYPES OF LEADERSHIP: WHICH ONE IS THE MOST INFLUENTIAL IN STAFFS PERFORMANCE (A Study On Performance In A Religious School
Setting). Dinasti International Journal of Education Management And Social Science, $\quad 1(2), \quad 172-182$. https://doi.org/10.31933/dijemss.v1i2.68

Misbach, I. H. (2010). Dahsyatnya Sidik Jari Menguak Bakat dan Potensi untuk Merancang Masa Depan Melalui Fingerprint Analysis. Jakarta: Visi Media.

Musrofi. (2011). Potensi Preneur. Surakarta: Talents Center.

Murakami, K. (2012). The Miracle of DNA. Bandung: Mizan Media Utama.

Murakami, K. (2013). Misteri DNA. Jakarta: Gramedia.

Nyarko, K. (2011). The Influence of Authoritative Parenting Style on Adolescents Academic Achievement. American Journal of Social and Management Science.

Oktafiany, N. D. dkk. (2013). Correlation of Parenting Method to the Sudents Emotional Quotients of Diponegoro 1 Jakarta Junior High School. Jurnal UNJ Online, 1(2).

Othman, N. \& Khairollah, S. (2013). Exploring the Relationship between Islamic Personality and Parenting Style. International Journal of Islamic Thought, 4.

Pratiwi, S. 2015). Kecerdasan Moral Anak Usia Prasekolah Etnis Cina Ditinjau dari Gaya Pengasuhan Orang Tua. Proceeding Seminar Nasional Positive Psychology 2015. Surabaya: Unika Widya Mandala.

Puskur. (2011). Pedoman Pelaksanaan Pendidikan Karakter. Jakarta: Balitbang Kemendiknas.

Puspitawati, H. \& Sarma, M. (2012). Sinergisme Keluarga dan Sekolah. Bogor: IPB Press.

Purwanto, A., Wijayanti, L.M., Hyun, C.C., Asbari, M. (2020). The Effects of Transformational, Transactional, authentic, Authoritarian Leadership style Toward Lecture Performance of Private University in Tangerang. Dinasti International Journal of Digital Business Management (DIJDBM), 1(1), 2942.DOI:https://doi.org/10.31933/dijdbm. v1i1.88 
Jurnal Edumaspul, 4 (1), Year 2020 - 155

(Masduki Asbari, Wakhida Nurhayati, Agus Purwanto' Firdaus Putra)

Poniman, F. \& Mangussara, R.A. (2012). Konsep Palugada STIFIn. Jakarta: STIFIn Institute.

Poniman, F. \& Mangussara, R.A. (2013). STIFIn Personality. Jakarta: STIFIn Institute.

Poniman dkk. (2014). Kubik Leadership Solusi Esensial Meraih Sukses dan Hidup Mulia. Jakarta: Kompas Gramedia.

Robinson, C. et.al. (1995). Authoritative, Authoritarian and Permissive Parenting Practices: Development of a New Measure. Psychological Reports, 77, 819-830.

Roman, N. et.al. (2015). Parenting Styles and Psychological Needs Influences on Adolescent Life Goals and Aspirations in A south African Setting. Journal of Psychology in Africa, 25(4).

Santrock, J. W. (2008). Psikologi Pendidikan. Jakarta: Kencana Prenada.

Samani, M. \& Hariyanto. (2011). Konsep dan Model Pendidikan Karakter. Bandung: Remaja Rosdakarya.

Setiawan, D. (2018, Maret 6). KPAI Catat Anak Dimanfaatkan Jadi Kurir Narkoba. $<$ https://www.kpai.go.id/berita/kpaicatat-anak-dimanfaatkan-jadi-kurirnarkoba> Diakses: 15 Oktober 2019.

Sugiyono. (2014). Metode Penelitian Kuantitatif dan Kualitatif. Bandung: Alfabeta.

Talib, Johari et.al. (2011). Effects of Parenting Style on Children Development. World Journal of Social Sciences, $1(2)$.

Utomo, D. (2014). Intensi Perilaku Prososial Anak Ditinjau dari Gaya Pengasuhan. Jurnal Online Psikologi, 2(1). 